\title{
Chronic toxicity of the antiepileptic carbamazepine on the clam Ruditapes philippinarum
}

\author{
Ângela Almeida a , Rosa Freitas a,b,*, Vânia Calisto ${ }^{\mathrm{b}, \mathrm{c}}$, Valdemar I. Esteves ${ }^{\mathrm{b}, \mathrm{c}}$, Rudolf J. Schneider ${ }^{\mathrm{d}}$, \\ Amadeu M.V.M. Soares ${ }^{\mathrm{a}, \mathrm{b}}$, Etelvina Figueira ${ }^{\mathrm{a}, \mathrm{b}}$ \\ a Biology Department, University of Aveiro, 3810-193 Aveiro, Portugal \\ b CESAM, University of Aveiro, 3810-193 Aveiro, Portugal \\ c Chemistry Department, University of Aveiro, 3810-193 Aveiro, Portugal \\ d BAM Federal Institute for Materials Research and Testing, Richard-Willstaetter-Str. 11, D-12489 Berlin, Germany
}

\section{A R T I C L E I N F O}

\section{Article history:}

Received 24 March 2015

Received in revised form 20 April 2015

Accepted 23 April 2015

Available online 2 May 2015

\section{Keywords:}

Biomarkers

Bivalves

Chronic toxicity

Pharmaceutical drugs

\begin{abstract}
A B S T R A C T
The impacts of carbamazepine (CBZ) on aquatic organisms are yet not well investigated. The present study aimed to better understand the chronic effects of environmentally relevant concentrations of CBZ. The experiment was performed by exposing the filter feeding clam Ruditapes philippinarum to $0.00,0.03,0.30,3.00$ and $9.00 \mu \mathrm{g} / \mathrm{L}$, during 28 days. To assess the chronic toxicity of the drug a battery of biomarkers related with health status and oxidative stress was applied. In order to quantify CBZ in the clam's tissues and in water samples ELISA was used. The present study showed three types of responses on the clams after a chronic exposure to CBZ. For control condition and the lower concentrations $(0.03$ and $0.30 \mu \mathrm{g} / \mathrm{L})$ a "similar" metabolic state was observed and the most efficient antioxidant status leading to the elimination of reactive oxygen species formed during the metabolism of CBZ. The concentration of $3.00 \mu \mathrm{g} / \mathrm{L}$ seemed to be a "threshold" concentration, beyond which the concentration levels of CBZ began to exert a toxic effect, compromising the activity of biotransformation and antioxidant enzymes, with notorious effects at the highest CBZ concentration $(9.00 \mu \mathrm{g} / \mathrm{L}) . \mathrm{CBZ}$ also seemed to alter the energy-related responses, especially the glycogen and electron system responses, revealing a slowdown in metabolism at the higher exposure concentrations (3.00 and $9.00 \mu \mathrm{g} / \mathrm{L}$ ). Overall, the present study demonstrated that the higher $\mathrm{CBZ}$ concentrations can lead to the impairment of antioxidant enzymes compromising the neutralization of reactive oxygen species, and thus the ability to cope with oxidative stress.
\end{abstract}

(c) 2015 Elsevier Inc. All rights reserved.

\section{Introduction}

Pharmaceuticals are used throughout the world being not only applied in human medicine but also in livestock breeding and aquaculture (Heberer et al., 2002; Boxall et al., 2004). Many of the pharmaceutical drugs applied in human/animal medicine are not completely metabolized by the organism, being excreted as a mixture of the unchanged compound, metabolites (active or inactive) or conjugates (mostly glucuronides and sulfates) (Daughton and Ternes, 1999; Heberer et al., 2002). Once excreted, these drugs reach the environment directly or via Wastewater Treatment Plants (WWTPs), where the majority end up passing unaltered through the conventional removal treatments applied (Monteiro and Boxall, 2010). As a consequence, the drugs are released in the environment possibly reaching concentrations that will trigger toxic effects on non-target organisms. If the

\footnotetext{
* Corresponding author at: Departamento de Biologia, Universidade de Aveiro, Campus Universitário de Santiago, 3810-193 Aveiro, Portugal. Tel.: + 351 234370782; fax: + 351 234372587.

E-mail address: rosafreitas@ua.pt (R. Freitas).
}

organisms possess receptors interacting with the drug effects may arise on them (Gunnarsson et al., 2008). Bivalves, due to their filter feeding and respiration capacities (McEneff et al., 2014), are among the most threatened organisms to the presence of contaminants in the water column (Gagné et al., 2006a). The uptake of pharmaceutical residues in wild bivalves has been previously shown (Klosterhaus et al., 2013; Martínez-Bueno et al., 2013), and trace concentrations of drugs were already detected in cooked seafood (McEneff et al., 2013). However few studies addressed the effects of those contaminants on these organisms (e.g. Gagné et al., 2006a; Canesi et al., 2007; Parolini and Binelli, 2012), being necessary additional information to better understand the toxicity that drugs may pose to this group of marine invertebrates.

Among pharmaceutical drugs commonly detected in the aquatic environment, carbamazepine (CBZ) is the most representative compound belonging to the class of antiepileptic pharmaceuticals (Mohapatra et al., 2014). This drug has antiepileptic and psychotropic properties, exerting its effects by blocking the sodium channels of excitatory neurons (Malarvizhi et al., 2012). The high consumption and the low degradation rate upon WWTPs $(<10 \%)$ (Zhang et al., 2008) are the principal reasons for the occurrence of CBZ in water bodies, namely in WWTP 
influents and effluents, surface waters, groundwater and even in treated drinking water, with concentrations ranging from 0.03 to $6.3 \mu \mathrm{g} / \mathrm{L}$ (Ternes, 1998; Sacher et al., 2001; Ferrari et al., 2003; Metcalfe et al., 2003; Bahlmann et al., 2009, 2012; Calisto et al., 2011a).

Although a vast literature is available about the quantification of pharmaceutical drugs in environmental samples, there is still a long way to go through regarding their toxic impacts, especially concerning chronic exposures, since the majority of works looking at the biological effects of pharmaceuticals have thus far concentrated on acute studies (Quinn et al., 2008). Furthermore, since CBZ is a persistent drug when released into the environment, requiring between 4.5 and 25 sunny summer days for its elimination (Calisto et al., 2011b), the evaluation of a long-term exposure is necessary to fully understand the impact of persistent drugs on aquatic organisms. Studies focusing on acute toxicity found that, in general, the CBZ concentrations causing effects occur in the $\mathrm{mg} / \mathrm{L}$ range (Malarvizhi et al., 2012), which are not representative of those concentrations occurring in the aquatic ecosystem, thus, leading to conclude that the risk of acute toxic effects in the environment is unlikely (Fent et al., 2006). However, considering that pharmaceutical drugs are continuously discharged into aquatic media, the assessment of chronic toxicity is of upmost importance. Furthermore, aquatic organisms downstream WWTP effluents are chronically exposed to a complex mixture of synthetic and biologically active pharmaceuticals which may impair important biological processes (Liu et al., 2015). Ferrari et al. (2003) studied the acute and chronic effects of CBZ, on the microcrustacean Ceriodaphnia dubia, observing that the chronic tests displayed higher toxicity than the acute assays. Other authors found a similar pattern, where the chronic tests presented a higher toxicity than the acute tests (e.g. Oetken et al., 2005; Zhang et al., 2012). Moreover, chronic studies performed with environmental concentrations have shown that CBZ can affect multiple oxidative and biochemical pathways in bivalves, with significant deleterious effects (Martin-Diaz et al., 2009; Contardo-Jara et al., 2011; Chen et al., 2014). The impact of CBZ was reported in other species, namely algae (Tsiaka et al., 2013), crustacean (Aguirre-Martínez et al., 2013a) and fish (Gagné et al., 2006a; Li et al., 2009, 2010).

Despite the literature concerning CBZ toxicity, the impact of CBZ on aquatic organisms is still poorly studied (Chen et al., 2014). The present study aimed to determine the effects of a chronic exposure (28 days) to environmentally relevant concentrations of CBZ $(0.00-9.00 \mu \mathrm{g} / \mathrm{L})$ in the clam Ruditapes philippinarum. The cost-effective immunoassay ELISA (Enzyme-Linked ImmunoSorbent Assay) was used for CBZ quantification in the bivalve's homogenates and the toxicity of $\mathrm{CBZ}$ was evaluated by the analysis of a battery of physiological and biochemical parameters.

\section{Materials and methods}

\subsection{Study area and test organism}

The Ria de Aveiro is a shallow estuary located in the Northwest Atlantic coast of Portugal, which comprises a complex net of channels and wide intertidal areas (mudflats and salt marshes) (Jonkers et al., 2010). This aquatic system has three main channels radiating from the sea entrance, named Mira, São Jacinto and Îlhavo. The lagoon has been influenced by human activities, where the anthropogenic pressure derived from population settlement and the industrial and harbor structures have an important impact. In this way, the Ria de Aveiro has been affected by environmental contamination with pharmaceutically active compounds such as CBZ. Recently, Calisto et al. (2011a) detected CBZ in one of eleven surface water samples from the Ria de Aveiro collected in a coastal touristic area as well as in wastewaters from two main WWTPs of Aveiro with concentrations ranging between 0.1 and $0.7 \mu \mathrm{g} / \mathrm{L}$. However, CBZ was not found in the Mira channel (Calisto et al., 2011a). According to Castro et al. (2006) this channel is the least impacted due to the low industrial and harbor activity and to the less dense human settlements. Freitas et al. (2014) pointed out that Mira channel is relatively pristine due to the low metal and metalloid concentrations. For these reasons, the Mira channel was chosen as the sampling area for this study.

R. philippinarum (Adams \& Reeve, 1850), commonly known as the Manila clam, was selected to study the ecotoxicological impact of CBZ in the Ria de Aveiro. This species has already been used in previous studies, under laboratory and field conditions, to assess the toxicity of CBZ (Aguirre-Martínez et al., 2013a, 2013b; Almeida et al., 2014) as well as other pharmaceutical drugs (Contardo-Jara et al., 2011; Matozzo et al., 2012a; Antunes et al., 2013; Milan et al., 2013) and to assess organic and metal pollution (Riba et al., 2004; Martín-Díaz et al., 2007; Figueira et al., 2012). All these studies demonstrated the suitability of R. philippinarum as a bioindicator species in marine environment quality assessment.

For laboratory experiments 90 individuals with similar size (mean length: $4.17 \pm 0.3 \mathrm{~cm}$; mean width: $3.22 \pm 0.4 \mathrm{~cm}$ ) were selected in order to minimize the effect of body weight on biochemical response and CBZ uptake. After sampling, organisms were transported to the laboratory where they were depurated during 8 days in seawater (salinity $25.0 \mathrm{~g} / \mathrm{L}$ ), under continuous aeration, constant temperature of $18 \pm 1{ }^{\circ} \mathrm{C}$ and a photoperiod of $12: 12 \mathrm{~h}$ (light/dark). The clams were fed with Algamac protein plus (150,000 cells/animal) every other day.

\subsection{Experimental conditions - toxicity tests}

The chronic toxicity assay lasted 28 days and the organisms of $R$. philippinarum were distributed by five concentrations of CBZ (control $=0.00 ; 0.03 ; 0.30,3.00$ and $9.00 \mu \mathrm{g} / \mathrm{L}$ ). The tested concentration range of $\mathrm{CBZ}$ was selected based on concentrations found in the environment and at the Ria de Aveiro (0.03 to $6.3 \mu \mathrm{g} / \mathrm{L}$; Bahlmann et al., 2009, 2012; Calisto et al., 2011a; Ferrari et al., 2003; Metcalfe et al., 2003; Sacher et al., 2001; Ternes, 1998). The highest concentration $(9.00 \mu \mathrm{g} / \mathrm{L})$ was selected to simulate an increase in CBZ discharges into the aquatic environment. For each concentration 18 individuals were used, placed each one in a different plastic container. Each container was filled with $300 \mathrm{~mL}$ of medium (artificial seawater, salinity $25.0 \mathrm{~g} / \mathrm{L}$ ), and submitted to continuous aeration, a temperature of $18 \pm 1{ }^{\circ} \mathrm{C}$ and a photoperiod of $12: 12 \mathrm{~h}$ (light/dark). Daily, animals were checked for mortality and every other day they were fed with Algamac protein plus (150,000 cells/animal). Clams were considered dead when their shells gaped and failed to shut again after external stimulus. During the experiment, the water was renewed twice a week and the concentrations re-established. At the end of exposure, the surviving organisms were frozen for further analysis.

\subsection{Physiological parameters}

\subsubsection{Condition index}

The condition index $(\mathrm{Cl})$ was determined according to Matozzo et al. (2012b) using 5 clams per conditions. CI values were calculated corresponding to the percentage of the ratio between the dry weight of the soft tissues ( $\mathrm{g}$ ) and the dry weight of the shell $(\mathrm{g})$.

\subsubsection{Clearance rate}

The clearance rate (CR) was determined according to Coughlan (1969), based on the absorption rate of a neutral red dye by clams (Masilamoni et al., 2002). Following the chronic exposure, 5 clams per condition were contaminated with a Congo Red solution $(15 \mathrm{mg} / \mathrm{L})$. After observing the valve aperture and during $5 \mathrm{~h}$ with intervals of $1 \mathrm{~h}$, the dye concentration in aliquots of $1 \mathrm{~mL}$ of the solution was measured spectrophotometrically at $498 \mathrm{~nm}$. The clearance rate $(\mathrm{L} / \mathrm{h})$ was calculated using the equation (Coughlan, 1969):

$$
\mathrm{CR}=\frac{\mathrm{V}}{\mathrm{nt}} \times \log \left(\mathrm{C}_{\mathrm{i}} / \mathrm{C}_{\mathrm{t}}\right)
$$


where $\mathrm{V}$ is the volume in the container $(\mathrm{L}), \mathrm{n}$ is the number of organisms used, $t$ is the time $(h), C_{i}$ is the initial concentration of the dye, and $C_{t}$ is the final concentration after time $t$.

\subsection{Carbamazepine quantification by ELISA}

\subsubsection{Sample preparation}

Carbamazepine quantification was performed in clam tissues after the exposure. The soft tissues of frozen organisms (5 per condition) were mechanically pulverized, in a mill, with liquid nitrogen. For each organism, the pulverized tissues were distributed in aliquots of $0.5 \mathrm{~g}$. The samples were sonicated for $15 \mathrm{~s}$ at $4{ }^{\circ} \mathrm{C}$, centrifuged for $10 \mathrm{~min}$ at $10,000 \mathrm{~g}$ at $4^{\circ} \mathrm{C}$. Clams' supernatants were obtained by extraction of pulverized tissues $(0.5 \mathrm{~g})$ with deionized water $(1: 2, \mathrm{w} / \mathrm{v})$. Moreover, the variation of $\mathrm{CBZ}$ in the water where the clams were exposed during the chronic assay was assessed at the beginning and at the end of the assay.

\subsubsection{Immunoassay procedure and calibration curve}

Few studies are available in the literature regarding the application of immunoassays to quantify CBZ in biological tissues. Gagné et al. (2006b) determined CBZ in the freshwater mussel (Elliptio complanata) soft tissue homogenate extracts using a competitive enzymatic immunoassay. In the present study, CBZ was quantified based on the direct competitive ELISA assay (Enzyme-Linked ImmunoSorbent Assay), according to the procedure developed by Bahlmann et al. (2009) and the modifications referred by Almeida et al. (2014). Good recoveries were previously demonstrated using ELISA to quantify CBZ in $R$. philippinarum homogenate extracts, with no matrix interferences and with no sample pre-treatment, turning the assay suitable for large and economic environmental screenings (Almeida et al., 2014). This assay is based on a direct competition of the antigen (CBZ) and tracer (CBZ analogue linked to the enzyme horseradish peroxidase) for the primary antibody (monoclonal antibody against CBZ) binding sites that are immobilized in a 96-well microtiter plate via a secondary antibody. High-binding microtiter plates were coated with this polyclonal antibody against mouse IgG $(1 \mathrm{mg} / \mathrm{L}, 200 \mu \mathrm{L}$ per well $)$ diluted in phosphate buffered saline (PBS) (10 mM sodium dihydrogen phosphate, $70 \mathrm{mM}$ sodium hydrogen phosphate, $145 \mathrm{mM}$ sodium chloride, $\mathrm{pH}$ 7.6). The plates were covered with Parafilm ${ }^{\circledR}$ to prevent evaporation and incubated overnight (approximately 16 to $18 \mathrm{~h}$ ) on a Titramax 100 plate shaker at $900 \mathrm{rpm}$. After overnight incubation, the plates were washed three times with PBS containing $0.05 \%(\mathrm{v} /$ v) Tween ${ }^{\mathrm{TM}} 20$ (PBS-T) using an automatic 8-channel plate washer. The monoclonal antibody against carbamazepine was also diluted in PBS $\left(7.61 \times 10^{-5} \mathrm{mg} / \mathrm{mL}, 200 \mu \mathrm{L}\right.$ per well $)$, added and incubated for $1 \mathrm{~h}$. Then, a new three-cycle washing step of the plate was performed. Afterwards, $50 \mu \mathrm{L}$ of tracer solution $(147 \mathrm{pmol} / \mathrm{L}$ in sample buffer) and $150 \mu \mathrm{L}$ of CBZ standard solutions or samples were added per well and incubated for $30 \mathrm{~min}$. The sample buffer consisted of $1 \mathrm{M}$ glycine, $3 \mathrm{M}$ sodium chloride and $2 \%(\mathrm{w} / \mathrm{v})$ of EDTA, pH 9.5. After another three-cycle washing step (PBS-T), $200 \mu \mathrm{L}$ of substrate solution was added per well and incubated for $30 \mathrm{~min}$. The substrate solution consisted of $540 \mu \mathrm{L}$ TMB-based solution $(41 \mathrm{mM}$ 3,3',5,5'-tetramethylbenzidine (TMB), 8 mM tetrabutylammonium borohydride (TBABH) prepared in dimethylacetamide (DMA) under nitrogen atmosphere) in $21.5 \mathrm{~mL}$ of substrate buffer ( $220 \mathrm{mM}$ citric acid, $0.66 \mathrm{mM}$ sorbic acid potassium salt and $3 \mathrm{mM}$ hydrogen peroxide). The TMB solution was freshly prepared for each run. The enzyme reaction was stopped by the addition of $1 \mathrm{M}$ sulfuric acid ( $100 \mu \mathrm{L}$ per well) and the optical density was read on a microplate spectrophotometer at $450 \mathrm{~nm}$ and referenced to $650 \mathrm{~nm}$. Data was analyzed using SoftMax ${ }^{\circledR}$ Pro Software (version 5.3, Molecular Devices). All samples and standards were determined in triplicate on each plate. A four-parametric logistic equation (4PL) (Findlay and Dillard, 2007) was fitted to the standards' mean values.
A calibration curve was performed for each plate using eight calibrators, with concentrations between 0 and $100 \mu \mathrm{g} / \mathrm{L}$ for a better convergence of the curve fitting. For the analysis of the clams' supernatants, the standards were prepared, in ultrapure water, by diluting a $10 \mathrm{mg} / \mathrm{L}$ stock solution of CBZ (also prepared in ultrapure water). For the analysis of water samples, the standards were prepared in seawater ( $25 \mathrm{~g} / \mathrm{L} \mathrm{NaCl}$ ) by diluting a stock solution of CBZ of the same concentration in order to minimize the effects of the water salinity in the CBZ quantification.

\subsection{Biomarker measurements}

For the biomarker measurements the supernatants obtained from the pulverized soft tissues $(0.5 \mathrm{~g})$, prepared as referred before, were extracted with the specific buffer for each analysis $(1: 2, \mathrm{w} / \mathrm{v})$. For that, the samples were sonicated for $15 \mathrm{~s}$ at $4{ }^{\circ} \mathrm{C}$ and centrifuged for $10 \mathrm{~min}$ at $10,000 \mathrm{~g}$ at $4^{\circ} \mathrm{C}$. Supernatants were used to determine: glycogen (GLYC) content, protein (PROT) content, electron transport system (ETS) activity, lipid peroxidation (LPO), reduced (GSH) and oxidized (GSSG) glutathione content, superoxide dismutase (SOD) activity, catalase (CAT) activity, glutathione S-transferases (GSTs) activity and cytochrome P450 3A4 (CYP3A4) activity. All the biochemical parameters were determined twice, using the supernatants obtained for each one of five replicates (clams). For LPO, supernatants were extracted using 20\% (v/v) trichloroacetic acid (TCA). For CAT, SOD, GSTs, GLYC and PROT content, the extraction was done with sodium phosphate buffer ( $50 \mathrm{mM}$ sodium dihydrogen phosphate monohydrate; $50 \mathrm{mM}$ disodium hydrogen phosphate dihydrate; $1 \mathrm{mM}$ ethylenediamine tetraacetic acid disodium salt dihydrate (EDTA); $1 \%(\mathrm{v} / \mathrm{v})$ Triton X-100; $1 \%(\mathrm{v} / \mathrm{v})$ polyvinylpyrrolidone (PVP); $1 \mathrm{mM}$ dithiothreitol (DTT)). For ETS determination, supernatants were extracted in homogenizing buffer (0.1 M Tris$\mathrm{HCl} \mathrm{pH} \mathrm{8.5,15 \%} \mathrm{(w/v)} \mathrm{PVP,} 153 \mathrm{mM}$ magnesium sulfate $\left(\mathrm{MgSO}_{4}\right)$ and $0.2 \%(\mathrm{v} / \mathrm{v})$ Triton X-100. GSH and GSSG were determined using $0.6 \%$ sulfosalicylic acid in potassium phosphate buffer $(0.1 \mathrm{M}$ dipotassium phosphate; $0.1 \mathrm{M}$ potassium dihydrogen phosphate; 5 mM EDTA; 0.1\% (v/v) Triton X-100; pH 7.5). CYP3A4 activity were analyzed in supernatants extracted with sodium phosphate buffer, pH 7.4 (0.1 M sodium dihydrogen phosphate monohydrate; $0.15 \mathrm{M}$ potassium chloride (KCl); 1 mM EDTA; 1 mM DTT).

\subsubsection{Energy-related parameters}

Glycogen (GLYC) was quantified according to the sulfuric acid method (Dubois et al., 1956), using glucose standards (0-2 mg/mL). Absorbance was measured at $492 \mathrm{~nm}$. The concentration of glycogen was expressed in mg per $g$ of fresh weight (FW).

Protein (PROT) content was determined following the spectrophotometric method of Biuret (Robinson and Hogden, 1940), using bovine serum albumin (BSA) as standard $(0-40 \mathrm{mg} / \mathrm{mL})$. Absorbance was read at $540 \mathrm{~nm}$. Results were expressed in mg per $\mathrm{g}$ of FW.

The electron transport system (ETS) activity was measured based on King and Packard (1975) and the modifications performed by De Coen and Janssen (1997). The absorbance was read at $490 \mathrm{~nm}$ during 10 min with intervals of $25 \mathrm{~s}$. The amount of formazan formed was calculated using $=15,900 \mathrm{M}^{-1} \mathrm{~cm}^{-1}$ and the results expressed in $\mathrm{nmol} / \mathrm{min} / \mathrm{g}$ FW.

\subsubsection{Indicators of oxidative stress}

Lipid peroxidation (LPO) was measured according to Ohkawa et al. (1979) and modifications referred by Carregosa et al. (2014). Absorbance was read at $535 \mathrm{~nm}\left(\varepsilon=156 \mathrm{mM}^{-1} \mathrm{~cm}^{-1}\right)$. LPO levels were expressed in nmol of MDA formed per $\mathrm{g}$ of FW.

Reduced (GSH) and oxidized (GSSG) glutathione content were determined according to Rahman et al. (2007), using reduced and oxidized glutathione standards $(0-60 \mu \mathrm{mol} / \mathrm{L})$. Absorbance was measured 
at $412 \mathrm{~nm}$. The results were expressed as nmol per $\mathrm{g}$ of FW. The GSH/GSSG ratio was determined.

\subsubsection{Antioxidant enzymes}

Superoxide dismutase (SOD) activity was determined based on the method of Beauchamp and Fridovich (1971), with some adaptations (Carregosa et al., 2014). Standards of SOD were prepared (0.25-60 U/mL). SOD activity was measured spectrophotometrically at $560 \mathrm{~nm}$. The enzymatic activity was expressed in U/g of FW.

Catalase (CAT) activity was quantified according Johansson and Borg (1988) and modifications performed by Carregosa et al. (2014). Standards of formaldehyde (0-150 $\mu \mathrm{M})$ were prepared. Absorbance was read at $540 \mathrm{~nm}$. CAT activity was expressed in $\mathrm{U} / \mathrm{g}$ of FW.

\subsubsection{Biotransformation enzymes}

The activity of glutathione S-transferases (GSTs) was determined according to Habig et al. (1974) and the modifications described by Carregosa et al. (2014). GSTs activity was measured spectrophotometrically at $340 \mathrm{~nm}\left(\varepsilon=9.6 \mathrm{mM}^{-1} \mathrm{~cm}^{-1}\right)$. The enzymatic activity was expressed in $\mathrm{U} / \mathrm{g}$ of $\mathrm{FW}$

The activity of cytochrome P450 3A4 (CYP3A4) was determined using the clam's hepatopancreas. Standards of resorufin (0.01$0.08 \mu \mathrm{mol} / \mathrm{L}$ ) and the specific substrate, resorufin benzyl ether (BzRes) were used (Quinn et al., 2004). The signal from resorufin formation was read after the incubation with $5 \mathrm{mM}$ nicotinamide adenine dinucleotide phosphate (NADPH) by fluorometry (excitation wavelength $530 \mathrm{~nm}$, emission wavelength $585 \mathrm{~nm}$ ). Enzyme activity was expressed in $\mathrm{U} / \mathrm{g}$ of $\mathrm{FW}$.

\subsection{Data analysis}

The Bioconcentration Factor (BCF) was determined dividing the concentration of CBZ present in clams' tissues by the spiked CBZ concentration for each exposure condition (Gobas and Morrison, 2000).

Physiological and biochemical descriptors and CBZ concentration data were submitted to hypothesis testing using permutation multivariate analysis of variance with the PERMANOVA + add-on in PRIMER v6 (Anderson et al., 2008). A one-way hierarchical design, with CBZ exposure concentration as the main fixed factor, was followed in this analysis. The pseudo-F values in the PERMANOVA main tests were evaluated in terms of significance. When the main test revealed statistical significant differences pairwise comparisons were performed. The t-statistics in the pairwise comparisons were evaluated in terms of significance. Values lower than 0.05 were considered as significantly different. The null hypothesis tested was: no significant differences exist among exposure concentrations. Significant differences among exposure concentration were represented with letters.

The matrix gathering the biomarker responses per exposure concentration was used to calculate the Euclidean distance similarity matrix. This matrix was simplified through the calculation of the distance among centroid matrix based on the 5 exposure conditions, which was then submitted to ordination analysis, performed by Principal Coordinates (PCO). Pearson correlation vectors $(r>0.9)$ of biochemical and physiological response descriptors were provided as supplementary variables being superimposed on the top of the PCO graph.

\section{Results}

\subsection{Mortality}

At the end of the exposure (28 days) mortality was observed at the concentrations of 0.03 (5\%), $0.30(5 \%)$ and $3.00 \mu \mathrm{g} / \mathrm{L}(11 \%)$. At the control condition and $9.00 \mu \mathrm{g} / \mathrm{L}$ no mortality was recorded.
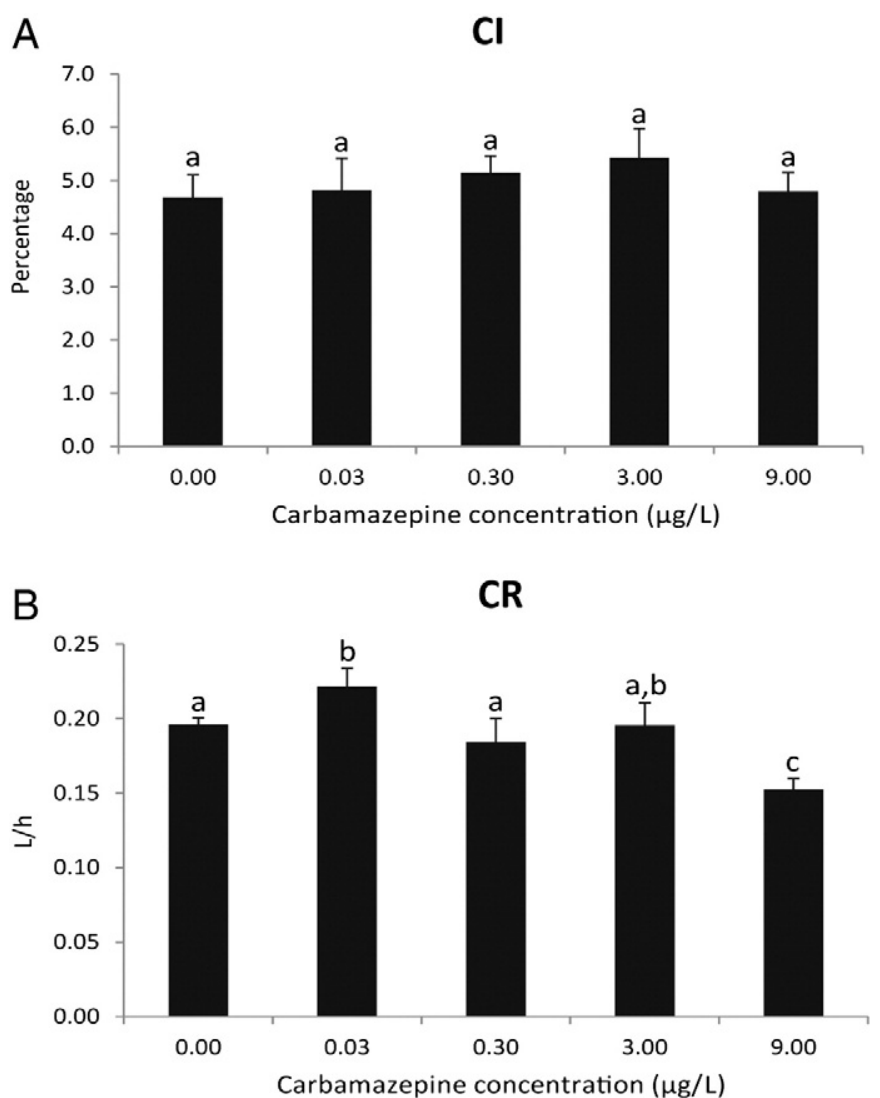

Fig. 1. Physiological parameters (A: $\mathrm{CI}$, condition index; $\mathrm{B}: \mathrm{CR}$, clearance rate) in $R$. philippinarum when exposed to increasing concentrations of CBZ during 28 days. Values are the mean (STDEV) of five replicates. Significant differences $(p \leq 0.05)$ among exposure concentrations are presented with letters $(\mathrm{a}-\mathrm{c})$.

\subsection{Physiological parameters}

Regarding the condition index $(\mathrm{CI})$ no significant differences were found across concentrations (Fig. 1A).

The results obtained for clearance rate (CR), presented in Fig. 1B, showed a significant decrease when $R$. philippinarum was exposed to CBZ $9.00 \mu \mathrm{g} / \mathrm{L}$ comparing with the remaining conditions. For lower CBZ concentrations the filtration rates were similar $(0.30$ and $3.00 \mu \mathrm{g} / \mathrm{L})$ or significantly higher $(0.03 \mu \mathrm{g} / \mathrm{L})$ than the values found at the control.

\subsection{Carbamazepine quantification by ELISA}

The results for CBZ quantification in $R$. philippinarum tissues revealed an increase in concentration along the exposure gradient (Table 1). Table 1 also presents the Bioconcentration Factor (BCF), showing a

Table 1

CBZ concentration (ng/g FW), determined by ELISA, and Bioconcentration Factor (BCF) in R. philippinarum tissues when exposed to increasing concentrations of CBZ during 28 days. Values are the mean (STDEV) of fifteen replicates. Significant differences $(p \leq 0.05)$ between exposure concentrations are presented with letters (a-d). $<$ LQ minor than the lower limit of the quantitation range $(0.024 \mu \mathrm{g} / \mathrm{L})$

\begin{tabular}{lll}
\hline Exposure concentration $(\mu \mathrm{g} / \mathrm{L})$ & CBZ in clams tissues $(\mathrm{ng} / \mathrm{g}$ FW) & BCF \\
\hline 0.00 & $<\mathrm{LQ}$ & - \\
0.03 & $0.03(0.01)^{\mathrm{a}}$ & $1.16(0.07)^{\mathrm{a}}$ \\
0.30 & $0.23(0.03)^{\mathrm{b}}$ & $0.9(0.1)^{\mathrm{b}}$ \\
3.00 & $3.6(0.4)^{\mathrm{c}}$ & $1.2(0.1)^{\mathrm{a}}$ \\
9.00 & $5.9(0.5)^{\mathrm{d}}$ & $0.7(0.1)^{\mathrm{c}}$ \\
\hline
\end{tabular}


Table 2

CBZ concentration $(\mu \mathrm{g} / \mathrm{L})$, determined by ELISA, in water where the clams were exposed to the chronic assay and in blanks at the beginning (day 0 ) and at the end of the assay (day 28). Significant differences $(p \leq 0.05)$ between exposure periods for CBZ in water from the chronic assay and in blanks are presented with letters (a). $<$ LQ minor than the lower limit of the quantitation range $(0.024 \mu \mathrm{g} / \mathrm{L})$.

\begin{tabular}{lllll}
\hline $\begin{array}{l}\text { Spiked } \\
\text { concentration } \\
(\mu \mathrm{g} / \mathrm{L})\end{array}$ & $\begin{array}{l}\text { CBZ in water } \\
(\mu \mathrm{g} / \mathrm{L})-\text { day } 0\end{array}$ & $\begin{array}{l}\text { CBZ in water } \\
(\mu \mathrm{g} / \mathrm{L})-\text { day } 28\end{array}$ & $\begin{array}{l}\text { Blanks } \\
(\mu \mathrm{g} / \mathrm{L})- \\
\text { day } 0\end{array}$ & $\begin{array}{l}\text { Blanks } \\
(\mu \mathrm{g} / \mathrm{L})-\text { day } \\
28\end{array}$ \\
\hline 0.00 & $<\mathrm{LQ}$ & $<\mathrm{LQ}$ & $<\mathrm{LQ}$ & $<\mathrm{LQ}$ \\
0.03 & $<\mathrm{LQ}$ & $<\mathrm{LQ}$ & $<\mathrm{LQ}$ & $<\mathrm{LQ}$ \\
0.30 & $0.26(0.02)^{\mathrm{a}}$ & $0.27(0.03)^{\mathrm{a}}$ & $0.25(0.02)^{\mathrm{a}}$ & $0.293(0.007)^{\mathrm{a}}$ \\
3.00 & $2.7(0.2)^{\mathrm{a}}$ & $2.9(0.4)^{\mathrm{a}}$ & $2.9(0.4)^{\mathrm{a}}$ & $3.02(0.08)^{\mathrm{a}}$ \\
9.00 & $10(1)^{\mathrm{a}}$ & $9(1)^{\mathrm{a}}$ & $10.6(0.8)^{\mathrm{a}}$ & $9(3)^{\mathrm{a}}$ \\
\hline
\end{tabular}

decreasing trend with the exposure to higher CBZ concentrations, although at $\mathrm{CBZ} 3.00 \mu \mathrm{g} / \mathrm{L}$ the levels were similar to the control. The quantification of $\mathrm{CBZ}$ in water where the clams were exposed during the assay (Table 2) showed that the concentration levels of exposure were maintained along the exposure.

\subsection{Biomarker measurements}

\subsubsection{Energy-related parameters}

The glycogen (GLYC) content significantly increased along the concentration gradient, especially at the highest concentration (Fig. 2A)

Protein (PROT) content showed a decreasing trend along the CBZ gradient, with significant differences at CBZ 0.30 and $9.00 \mu \mathrm{g} / \mathrm{L}$ (Fig. 2B).

The electron transport system (ETS) activity results (Fig. 2C) revealed a decreasing tendency after the exposure to CBZ. However, significant differences were only obtained between the control and the highest $\mathrm{CBZ}$ concentration.

\subsubsection{Indicators of oxidative stress}

$R$. philippinarum chronically exposed to CBZ exhibited lower LPO levels than the control, exception made for $3.00 \mu \mathrm{g} / \mathrm{L}$, where no significant differences were found compared to the control condition (Fig. 3A).

Reduced (GSH) and oxidized (GSSG) glutathione contents (Fig. 3B) differed between conditions: higher GSH and GSSG levels were found at CBZ 3.00 and $9.00 \mu \mathrm{g} / \mathrm{L}$, comparing with the remaining conditions; a significant decrease in GSH/GSSG (Fig. 3C) at the higher concentrations $(0.30,3.00$ and $9.00 \mu \mathrm{g} / \mathrm{L})$ by comparison with the control and $0.03 \mu \mathrm{g} / \mathrm{L}$ was noticed.

\subsubsection{Antioxidant enzymes}

Superoxide dismutase (SOD) activity depicted in Fig. 4A, showed a significant increase at all exposure concentrations compared to the control, except at CBZ $9.00 \mu \mathrm{g} / \mathrm{L}$ where no significant differences were found.

The activity of catalase (CAT) (Fig. 4B) showed no significant differences across all conditions, except at CBZ $0.03 \mu \mathrm{g} / \mathrm{L}$ where the activity of the enzyme was significantly lower compared to the control.

\subsubsection{Biotransformation enzymes}

The results for glutathione S-transferases (GSTs) are presented in Fig. 5A, showing no significant differences among conditions except at CBZ $3.00 \mu \mathrm{g} / \mathrm{L}$, where a significant increase in the activity of this family of enzymes was observed.

The activity of the cytochrome P450 3A4 (CYP3A4) was significantly induced after exposure to $\mathrm{CBZ}$, especially noticed at the lower concentrations $(0.03$ and $0.30 \mu \mathrm{g} / \mathrm{L}$ ) (Fig. $5 \mathrm{~B})$, decreasing at the higher CBZ concentrations ( 3.00 and $9.00 \mu \mathrm{g} / \mathrm{L}$ ), although being still higher than the control.

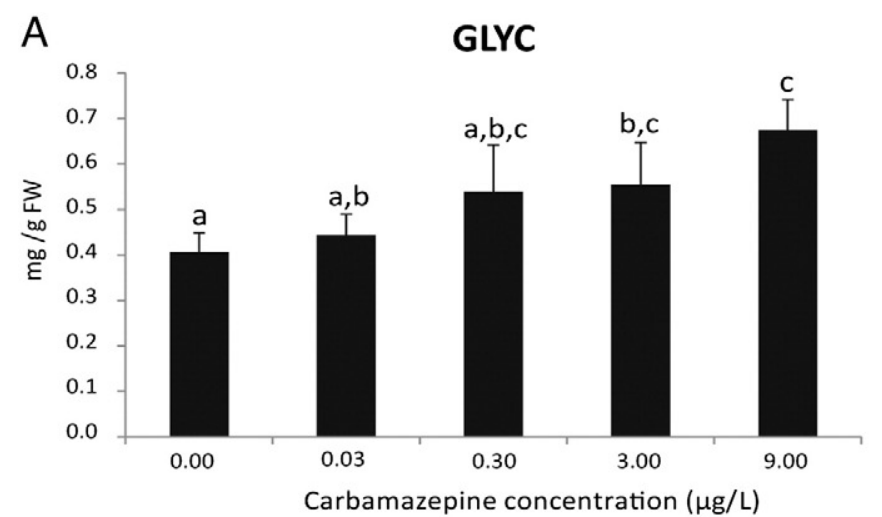

B
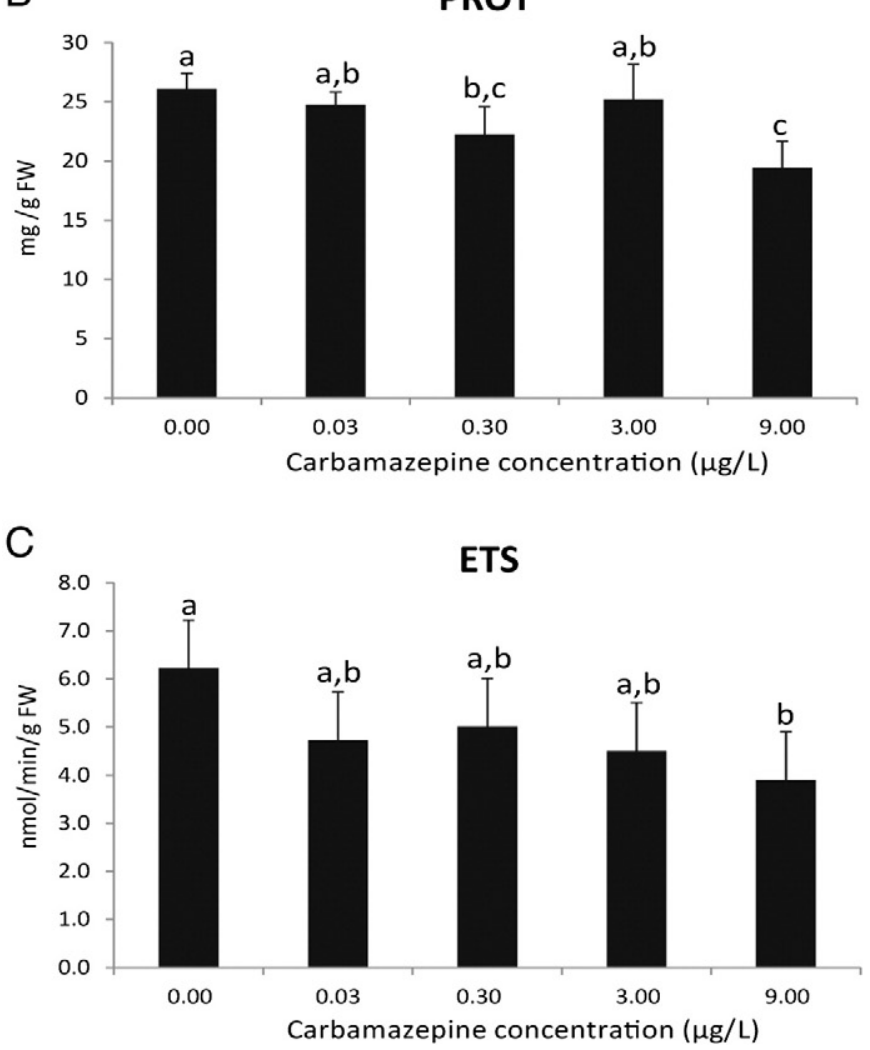

Fig. 2. Energy-related parameters (A: GLYC, glycogen; B: PROT, protein; C: ETS, electron transport system activity) in R. philippinarum when exposed to increasing concentrations of CBZ during 28 days. Values are the mean (STDEV) of five replicates. Significant differences $(p \leq 0.05)$ among exposure concentrations are presented with letters $(a-c)$.

\subsection{Multivariate analysis regarding clams' biochemical responses}

In Fig. 6 the centroid PCO ordination graph is represented resulting from applying a multivariate analysis to the physiological and biochemical parameters. The PCO axis 1 explained $40.2 \%$ of the total variation of data, separating the control at the negative side of the axis; 0.03 and $0.30 \mu \mathrm{g} / \mathrm{L}$ near the origin of the axis and 3.00 and $9.00 \mu \mathrm{g} / \mathrm{L}$ at the positive side. The PCO axis 2 explained $32.5 \%$ of the total data variation, separating the lower CBZ concentrations 0.03 and $0.30 \mu \mathrm{g} / \mathrm{L}$ (in the negative side of the axis) from the control, 3.00 and $9.00 \mu \mathrm{g} / \mathrm{L}$ (at the positive side of the axis). The clams exposed to the control condition were characterized by higher GSH/GSSG and ETS values; clams exposed to CBZ 0.03 and $0.30 \mu \mathrm{g} / \mathrm{L}$ were better correlated with CYP3A4 and lower LPO levels; CBZ $3.00 \mu \mathrm{g} / \mathrm{L}$ was best described by LPO and GSTs parameters and finally the highest CBZ concentration was well correlated to a higher GLYC content. 
A

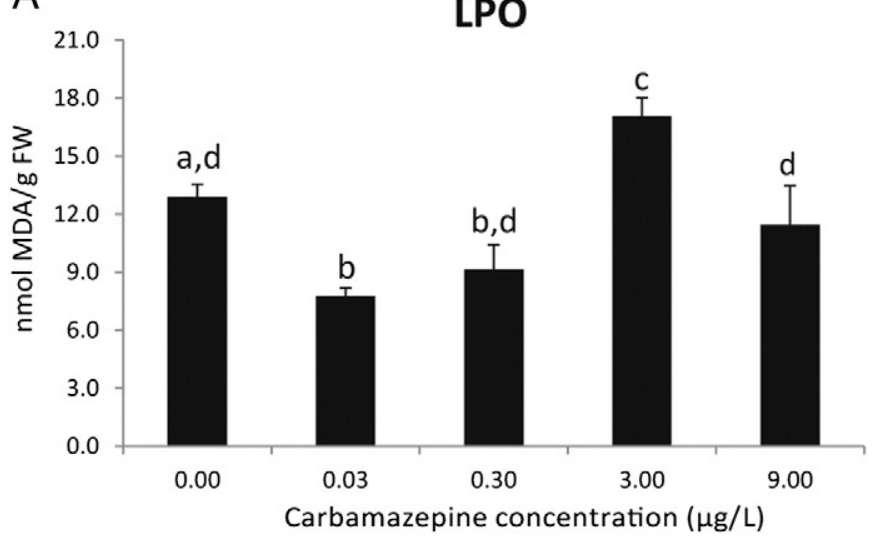

B

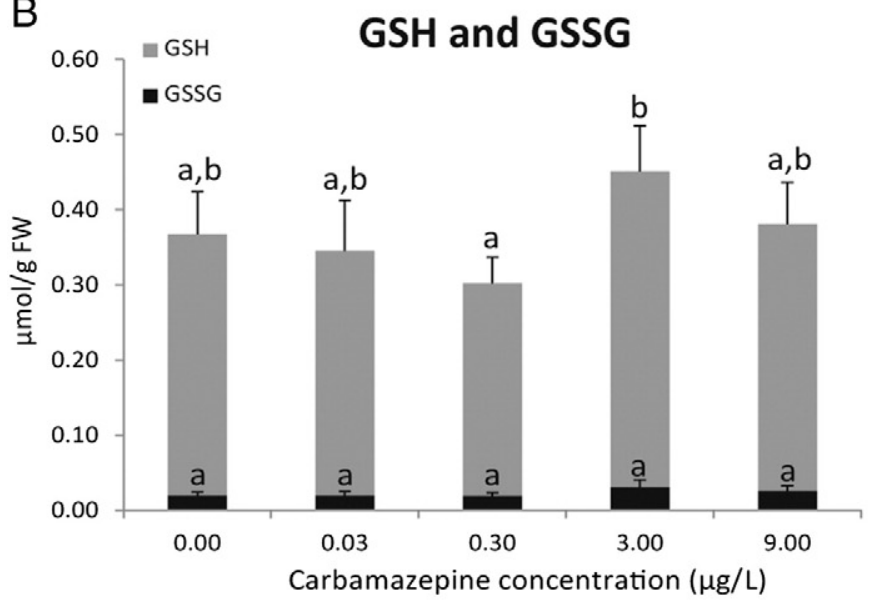

C

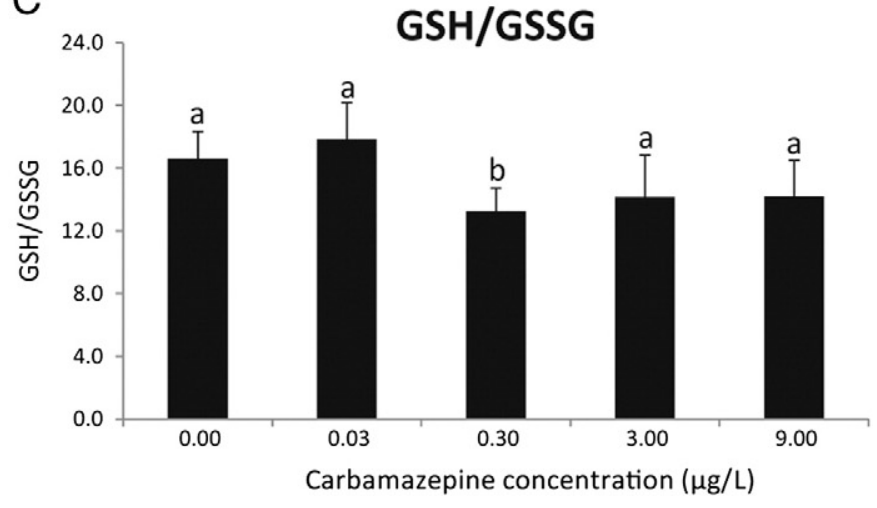

Fig. 3. Indicators of oxidative stress (A: LPO, lipid peroxidation; B: GSH, reduced glutathione; GSSG, oxidized glutathione; C: GSH/GSSG, ratio between reduced and oxidized glutathione) in R. philippinarum when exposed to increasing concentrations of CBZ during 28 days. Values are the mean (STDEV) of five replicates. Significant differences $(p \leq 0.05)$ among exposure concentrations are presented with letters (a-d).

\section{Discussion}

The toxic impact of CBZ has been assessed, with the majority of studies focusing on acute effects. These studies revealed that, in general, the concentrations causing toxic effects occur in the $\mathrm{mg} / \mathrm{L}$ range, which turns the risk of acute toxicity in the environment unlikely to occur. Other works pointed out the necessity to conduct more chronic tests since, in the environment, the organisms are exposed for long periods to pharmaceutical drugs. Recent studies assessing the chronic toxicity of drugs have been showing higher toxicity than the acute tests,
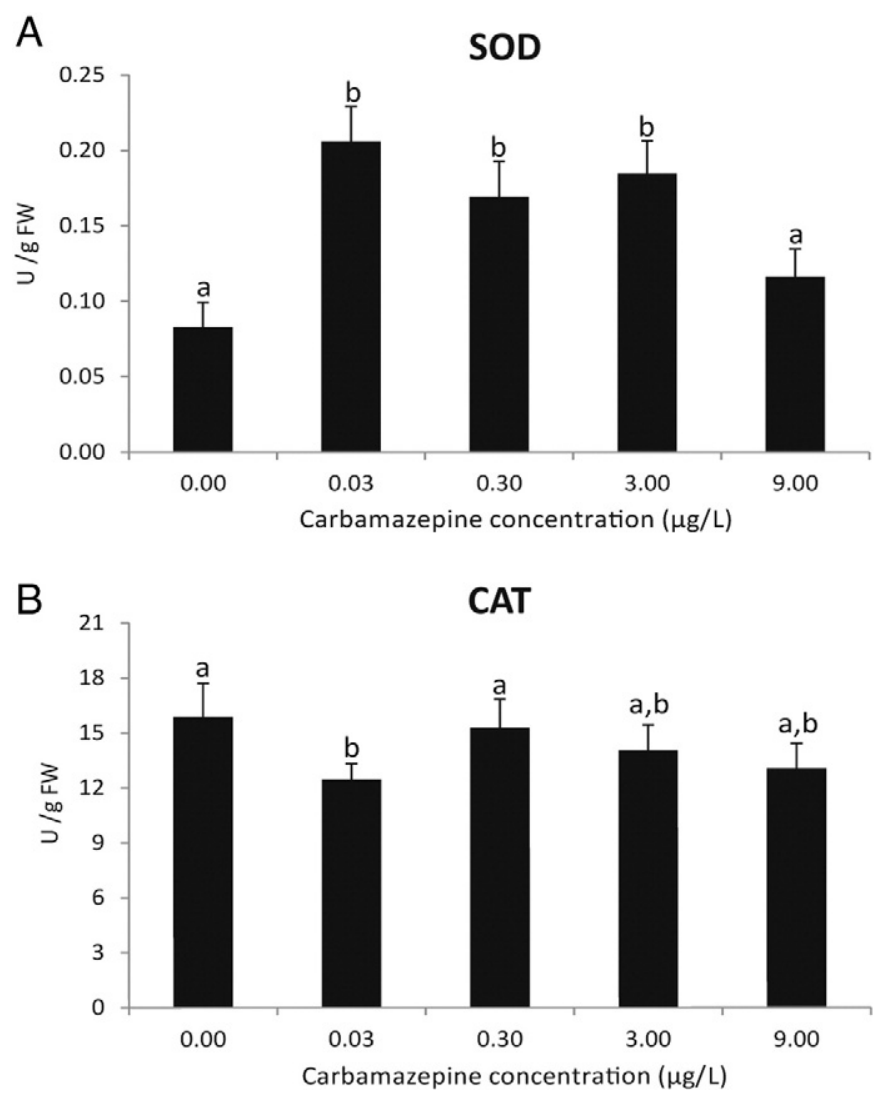

Fig. 4. Antioxidant enzymes (A: SOD, superoxide dismutase; B: CAT, catalase) in $R$. philippinarum when exposed to increasing concentrations of $\mathrm{CBZ}$ during 28 days. Values are the mean (STDEV) of five replicates. Significant differences $(p \leq 0.05)$ among exposure concentrations are presented with letters $(a, b)$.

revealing that aquatic organisms of different species (e.g. algae, crustaceans, fish) can be impaired even when exposed to environmentally relevant concentrations of drugs (Martin-Diaz et al., 2009; Li et al., 2010; Aguirre-Martínez et al., 2013a; Tsiaka et al., 2013; Chen et al., 2014).

The ability of organisms to accumulate CBZ (under laboratory or field conditions) has been reported in recent studies (Ramirez et al., 2007; Vernouillet et al., 2010; Contardo-Jara et al., 2011; Garcia et al., 2012; Martínez-Bueno et al., 2013). CBZ is relatively hydrophobic, enabling the capacity to partition into the lipid portion of the organisms and bioaccumulate (Liu et al., 2015). In the present study, CBZ in clam tissues increased with the increase of exposure concentration reaching a maximum of $\approx 6 \mathrm{ng} / \mathrm{g}$ FW at $9.00 \mu \mathrm{g} / \mathrm{L}$. Contardo-Jara et al. (2011) determined the accumulation of CBZ in the mussel Dreissena polymorpha after 1, 4 and 7 days of exposure, when submitted to concentrations ranging from 0.236 to $236 \mu \mathrm{g} / \mathrm{L}$ and an increase in the CBZ accumulation with the exposure time was found at all concentrations, demonstrating the risk of $\mathrm{CBZ}$ bioaccumulation in wildlife populations.

Regarding the Bioconcentration Factor (BCF), determined in this study, the higher values were found at CBZ 0.03 and $3.00 \mu \mathrm{g} / \mathrm{L}$, being approximately 1 and the lowest $(\approx 0.7)$ at $C B Z 9.00 \mu \mathrm{g} / \mathrm{L}$. In the study performed by Contardo-Jara et al. (2011) the highest BCF values were found at the lowest CBZ concentrations where the mussels exposed to $0.236 \mu \mathrm{g} / \mathrm{L}$ accumulated CBZ 17 -fold within 1 day. The BCF increased to 60 and 90 after 4 and 7 days of exposure, respectively. Garcia et al. (2012) compared the BCF (laboratory experiment) and BAF (field organisms) for CBZ in fish (Pimephales notatus, Ictalurus punctatus, Oreochromis niloticus) and found that BCF values ranged between 1.5 and 7.1, while BAFs ranged from 2.5 to 3.8 , suggesting that the accumulation of $\mathrm{CBZ}$ under laboratory and field conditions are similar. The 
A



B

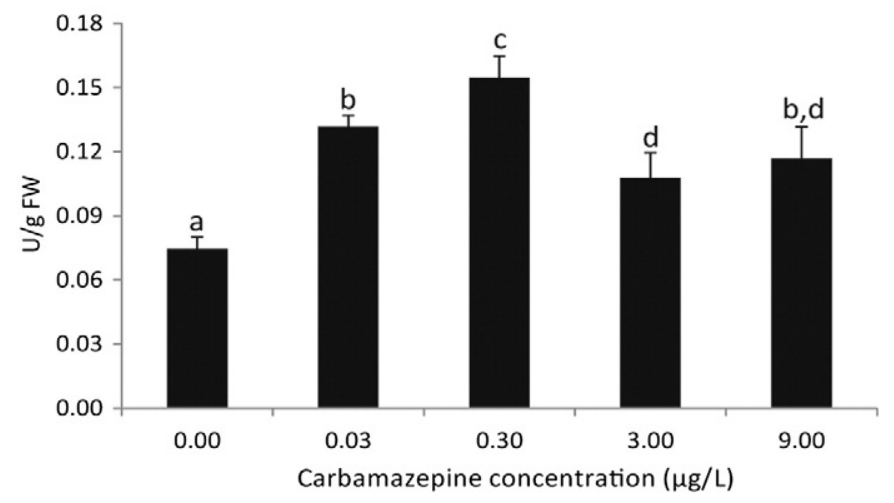

Fig. 5. Biotransformation enzymes (A: GSTs, glutathione S-transferases; B: CYP3A4, cytochrome P450 3A4) in R. philippinarum when exposed to increasing concentrations of CBZ during 28 days. Values are the mean (STDEV) of five replicates. Significant differences $(p \leq 0.05)$ among exposure concentrations are presented with letters (a-d).

lowest value observed for $\mathrm{BCF}$ in the present study $(\approx 0.7)$ may be justified by the results obtained for clearance rate $(C R)$. $C R$ values indicated that at the lowest CBZ concentrations, $R$. philippinarum has a filter activity similar to the control condition. However, at $9.00 \mu \mathrm{g} / \mathrm{L}$ a significant decrease in $\mathrm{CR}$ was observed, in comparison with the remaining conditions. At the highest concentration, this drug may be somehow signalized as harmful, being the rate of its uptake reduced as an attempt to limit the exposure to CBZ contamination. This defense behavior may explain the lowest mortality recorded at the highest $\mathrm{CBZ}$ concentration $(0 \%, 9.00 \mu \mathrm{g} / \mathrm{L})$ compared to the remaining exposure concentrations (between 5 and 11\%, 0.03-3.00 $\mu \mathrm{g} / \mathrm{L}$ ). Gosling (2003) reported that bivalves can isolate their tissues from the external environment by closing their valves thus, protecting themselves against contaminants. The closure of valves in the presence of CBZ was also observed by Chen et al. (2014) when submitting the freshwater clam Corbicula fluminea to 5 and $50 \mu \mathrm{g} / \mathrm{L}$ of CBZ, during 30 days, indicating that the exposure to environmentally relevant concentrations is enough to alter the siphoning behavior in these clams. With this strategy, that seems to be used as a last resort, and that was observed only at the highest concentration $(9.00 \mu \mathrm{g} / \mathrm{L})$ the clams try to mitigate the deleterious effects that an excessive accumulation of CBZ would trigger; however, the tested lowest concentrations appear not to be high enough to activate this mechanism. Indeed, at the lowest concentrations several changes on different biochemical parameters were observed. Thus, energy-related parameters, like glycogen (GLYC) or protein (PROT) content, were applied as indicators of environmental stress (Smolders et al., 2004). The use of these parameters in toxicological studies is relevant since they allow the measuring of the energy costs that a fight to a stress response entails

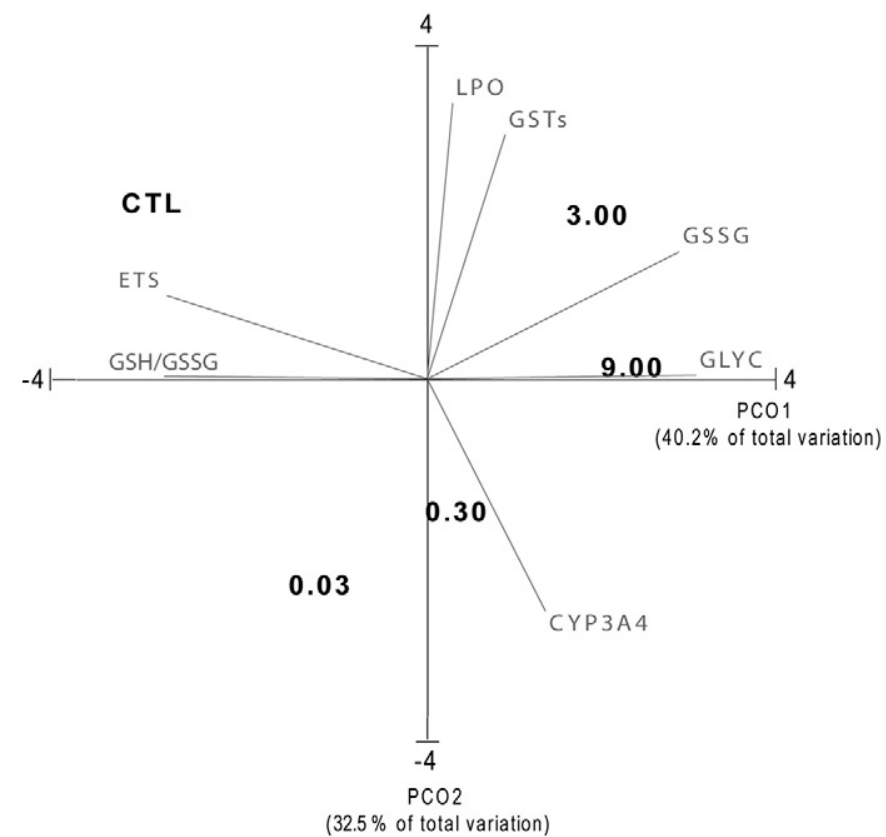

Fig. 6. Physiological and biochemical responses of $R$. philippinarum exposed to increasing CBZ concentrations during 28 days, plotted on axes 1 and 2 of a Principal Coordinates (PCO) graph. Physiological and biochemical responses are superimposed on the PCO $(r>0.9)$. The control (CTL) and concentrations of exposure $(0.03,0.30,3.00,9.00 \mu \mathrm{g} / \mathrm{L})$ are indicated. The biomarkers presented are: CYP3A4, cytochrome P45034A; ETS, electron transport system activity; GLYC, glycogen content; GSSG, oxidized glutathione; GSH/ GSSG, ratio between reduced and oxidized glutathione; GSTs, glutathione S-tansferases and LPO, lipid peroxidation.

to organisms (Smolders et al., 2004). The results obtained in the present study may indicate that at $\mathrm{CBZ} 9.00 \mu \mathrm{g} / \mathrm{L}$ the reduction of $\mathrm{CR}$ could result in a lower metabolic activity, thus, the internal storages as GLYC content would not decrease, as reported by Duquesne et al. (2004). These authors observed that the reduction in clearance rate in the bivalve Macoma balthica, as an attempt to limit the exposure to contamination, led to a slowdown in metabolism resulting in a relatively stable GLYC concentration. Under stress PROT content can either increase or decrease. Smolders et al. (2003) reported that low to intermediate levels of pollution trigger increased protein synthesis (e.g. metabolic defenses involved in detoxification processes), but decreased protein synthesis was also referred, being attributed to high concentrations of pollutants (Smolders et al., 2004), when organisms cannot handle oxidative stress. In the current work PROT content showed a decreasing trend along the $\mathrm{CBZ}$ gradient. These results may indicate that the protein budget is being depressed by the exposure to $C B Z$, especially at the highest $C B Z$ concentrations.

The balance between mitochondrial electron transport system (ETS) activity and energy reserves (sugars, lipids and proteins) has been reported as a relevant biochemical/physiological marker to predict changes in invertebrates (De Coen and Janssen, 1997; Smolders et al., 2004; Gagné et al., 2006c). In the present study the control condition presented the highest ETS activity, which suggests a higher metabolic rate leading to a higher expense of energy stores, as observed by the lowest GLYC content at this condition. ETS activity decreased along the exposure gradient which may reflect the reduction in CR and the slowdown of metabolism thus, mobilizing less energy stores, as GLYC.

The assessment of CBZ ecotoxicological impact revealed that the oxidative stress induced by CBZ in aquatic organisms is related to its accumulation (Quinn et al., 2008; Vernouillet et al., 2010; Contardo-Jara et al., 2011; Tsiaka et al., 2013). In the present study, LPO levels at the control condition were similar ( $11 \pm 2 \mathrm{nmol} \mathrm{MDA} / \mathrm{g}$ FW) to those found in clams collected from the environment. These results support 
the ETS activity at the control condition because a high ETS is related to a high generation of ROS (reactive oxygen species), since mitochondria are the principal site of their production. An increase in LPO levels occurred along CBZ 0.03, 0.30 and $3.00 \mu \mathrm{g} / \mathrm{L}$, but decreased at CBZ $9.00 \mu \mathrm{g} / \mathrm{L}$. At the highest CBZ concentrations, the ETS activity was significantly lower when compared to the remaining conditions, thus generating a lower content of ROS in mitochondria. But, the lower activity of the cytochrome P450 3A4 (CYP3A4), at this condition also accounted for the LPO decrease. This enzyme is involved in the biotransformation of CBZ, with generation of ROS as byproducts of the metabolization process. In the present work, at the lowest CBZ concentrations $(0.03,0.30 \mu \mathrm{g} / \mathrm{L})$ a higher CYP3A4 activity was observed, evidencing a higher capacity to metabolize CBZ and a low intracellular accumulation of the drug. However, this metabolization capacity was decreased in the presence of higher CBZ concentrations ( 3.00 and $9.00 \mu \mathrm{g} / \mathrm{L}$ ), possibly revealing that the high levels of the drug inhibit CYP3A4 activity, resulting in a higher cellular accumulation of CBZ. Antioxidant enzyme activity counteracts the damaging effects of ROS formed during the metabolization of CBZ. In this study, the higher SOD activity at the lower $\mathrm{CBZ}$ concentrations is in accordance with the results obtained for CYP3A4 since its activity is increased at the lower CBZ concentrations $(0.03,0.30 \mu \mathrm{g} / \mathrm{L})$. This increased enzymatic activity enhanced the elimination of ROS which were formed either by the metabolization of $\mathrm{CBZ}$ or by the ETS activity, thus conducting to a reduction in LPO levels, as observed for 0.03 and $0.30 \mu \mathrm{g} / \mathrm{L}$. At CBZ $3.00 \mu \mathrm{g} / \mathrm{L}$, SOD also seemed to be actively involved in the ROS elimination, but at CBZ $9.00 \mu \mathrm{g} / \mathrm{L}$ the enzymatic activity decreased, consequently increasing oxidative stress and LPO levels that did not reach higher values, due to the lower ETS activity. In the studies performed by Li et al. (2009) SOD activity decreased along the concentration gradient of CBZ $(0.1 \mu \mathrm{g} / \mathrm{L}, 0.2$ and $2 \mathrm{mg} / \mathrm{L})$ after a 21 day exposure of the rainbow trout, Oncorhynchus mykiss. After a prolonged exposure ( 42 days), a strong inhibition of SOD activity was observed and attributed to the overproduction of ROS and the relatively low activity of the antioxidant system.

The activity of catalase (CAT) is related with SOD activity, since CAT decomposes the hydrogen peroxide produced by SOD into water and oxygen. However, in the present study, the CAT activity did not change significantly after the exposure to CBZ. Similarly, Martin-Diaz et al. (2009) reported no significant alteration on CAT activity in the mussel Mytilus galloprovincialis exposed to CBZ (10 $\mu \mathrm{g} / \mathrm{L}, 7$ days). On the other hand, Chen et al. (2014) observed that the increase in CAT activity after exposure of the clam $C$. fluminea to CBZ ( 5 and $50 \mu \mathrm{g} / \mathrm{L}, 30$ days) was due to the hydrogen peroxide formation resulting from the increase in superoxide anion production and its conversion by SOD. Our findings may indicate that the hydrogen peroxide produced by SOD is possibly being converted not by CAT but by another enzyme with the same role, as glutathione peroxidase (GPX).

Besides cytochrome P450 enzymes, GSTs are another family of biotransformation enzymes involved in drug metabolism. These enzymes are involved in the formation of thiol metabolites resulting from CBZ oxidation, in which GSH is conjugated with the carbonyl group of CBZ (Vernouillet et al., 2010). GST isoenzymes are also capable of inactivating lipoperoxidation products, such as lipid hydroperoxides (Sturve et al., 2008) by the use of GSH as a reducing agent that is oxidized to GSSG when peroxides are reduced (Contardo-Jara et al., 2010). In the present study, the activity of GSTs was only significantly increased at CBZ $3.00 \mu \mathrm{g} / \mathrm{L}$, in comparison with the remaining conditions, although a $20 \%$ increase of GST activity was noticed for the control and at $9.00 \mu \mathrm{g} / \mathrm{L}$ compared to 0.03 and $3.00 \mu \mathrm{g} / \mathrm{L}$. Despite the increase in GSTs activity at CBZ $3.00 \mu \mathrm{g} / \mathrm{L}$, possibly indicating an involvement in $\mathrm{CBZ}$ biotransformation, it seemed not to be very effective in the scavenging of the reactive metabolites, as the LPO levels were high at this condition. However, the high ROS concentrations might be due to intracellular CBZ increase and ETS activity. The increase of GSH at CBZ 3.00 and $9.00 \mu \mathrm{g} / \mathrm{L}$, one of the most important scavengers of ROS, may also indicate the high need of cells to neutralize ROS. GSH/GSSG ratio decreased at the higher CBZ concentrations $(0.30,3.00$ and $9.00 \mu \mathrm{g} / \mathrm{L})$ being indicative of the high oxidative status occurring at these conditions.

\section{Conclusions}

It is generally accepted that the presence of pharmaceutical drugs in the aquatic environment poses a risk to wildlife. Although it is unlikely that these contaminants will be found at concentrations high enough to illicit an acute effect, evidence is growing, suggesting that they may be present in concentrations high enough to cause chronic effects. Despite the effort that is being made to obtain more chronic and realistic data, there is yet a large gap concerning this issue. In this way, this work was performed in order to better understand the chronic effects of $\mathrm{CBZ}$, a ubiquitous pharmaceutical drug, in the aquatic environment.

Overall, the results obtained pointed out a dose-dependent effect. The control condition was described by higher GSH/GSSG ratio and ETS activity. Although presenting high LPO levels this was considered a "normal status" for the clams at this condition, revealing their high metabolic rate. The clams exposed to the lower CBZ concentrations $(0.03$ and $0.30 \mu \mathrm{g} / \mathrm{L})$ were well correlated with a high CBZ biotransformation, indicated by the high activity of CYP3A4 and the low CBZ accumulation. Part of the ROS formed during this step was eliminated by SOD. Nevertheless, the antioxidant system defenses seemed to be properly activated at these conditions. Finally, the clams exposed to the higher CBZ concentrations ( 3.00 and $9.00 \mu \mathrm{g} / \mathrm{L}$ ) were well correlated to LPO and GSSG data, indicating the higher oxidative environment at these conditions that possibly compromised the activity of SOD, CYP3A4 and GSTs (at CBZ $9.00 \mu \mathrm{g} / \mathrm{L}$ ). Moreover, the GLYC content was the parameter with the larger variation relative to $\mathrm{CBZ} 9.00 \mu \mathrm{g} / \mathrm{L}$, possibly revealing the metabolism slowdown. At this condition, the induction of GSH and the decrease of ETS were the only strategies to mitigate the oxidative damage, resulting from the high CBZ accumulation and the low enzymatic activity.

A prolonged exposure to CBZ leads to a strong inhibition of antioxidant enzymes, compromising the destruction of ROS and the control of the oxidative stress, evidencing the higher toxicity that a chronic exposure to CBZ induces in comparison with an acute exposure, especially concerning GLYC and LPO levels and CYP3A4 activity (Almeida et al., 2014).

\section{Acknowledgments}

This work was supported by the Portuguese Science Foundation (FCT) through CESAM: UID/AMB/50017/2013. Rosa Freitas and Vânia Calisto benefited from a post-doc grant (SFRH/BPD/92258/ 2013 and SFRH/BPD/78645/2011, respectively) given by the FCT.

\section{References}

Aguirre-Martínez, G.V., Buratti, V., Fabri, E., Del Valls, T.A., Martin-Diaz, M.L., 2013a. Using lysosomal membrane stability of haemocytes in Ruditapes philippinarum as a biomarker of cellular stress to assess contamination by caffeine, ibuprofen, carbamazepine and novobiocin. J. Environ. Sci. 25, 1408-1418. http://dx.doi.org/10.1016/S1001-0742(12)60207-1.

Aguirre-Martínez, G.V., DelValls, T.A., Martin-Diaz, M.L., 2013b. Early responses measured in the brachyuran crab Carcinus maenas exposed to carbamazepine and novobiocin: application of a 2-tier approach. Ecotoxicol. Environ. Saf. 97, 47-58. http://dx.doi. org/10.1016/j.ecoenv.2013.07.002.

Almeida, Â., Calisto, V., Esteves, V., Soares, A.M.V.M., Figueira, E., Freitas, R., 2014. Presence of carbamazepine in coastal systems: effects on bivalves. Aquat. Toxicol. 156, 74-87. http://dx.doi.org/10.1016/j.aquatox.2014.08.002

Anderson, M., Gorley, R.N., Clarke, R.K., 2008. Permanova + for Primer: Guide to Software and Statistical Methods. University of Auckland and PRIMER-E, Plymouth.

Antunes, S.C., Freitas, R., Figueira, E., Gonçalves, F., Nunes, B., 2013. Biochemical effects of acetaminophen in aquatic species: edible clams Venerupis decussata and Venerupis 
philippinarum. Environ. Sci. Pollut. Res. 20, 6658-6666. http://dx.doi.org/10.1007/ s11356-013-1784-9.

Bahlmann, A., Weller, M.G., Panne, U., Schneider, R.J., 2009. Monitoring carbamazepine in surface and wastewaters by an immunoassay based on a monoclonal antibody. Anal. Bioanal. Chem. 395, 1809-1820. http://dx.doi.org/10.1007/s00216-009-2958-7.

Bahlmann, A., Carvalho, J.J., Weller, M.G., Panne, U., Schneider, R.J., 2012. Immunoassays as high-throughput tools: monitoring spatial and temporal variations of carbamazepine, caffeine and cetirizine in surface and wastewaters. Chemosphere 89, 1278-1286. http://dx.doi.org/10.1016/j.chemosphere.2012.05.020.

Beauchamp, C., Fridovich, I., 1971. Superoxide dismutase: improved assays and an assay applicable to acrylamide gels. Anal. Biochem. 44, 276-287. http://dx.doi.org/10. 1016/0003-2697(71)90370-8.

Boxall, A.B.A., Fogg, L.A., Blackwell, P.K., Pemberton, E.J., Croxford, A., 2004. Veterinary medicines in the environment. Rev. Environ. Contam. Toxicol. 189, 1-91. http://dx. doi.org/10.1007/0-387-21729-0_1.

Calisto, V., Bahlmann, A., Schneider, R.J., Esteves, V.I., 2011a. Application of an ELISA to the quantification of carbamazepine in ground, surface and wastewaters and validation with LC-MS/MS. Chemosphere 84, 1708-1715. http://dx.doi.org/10.1016/j. chemosphere.2011.04.072.

Calisto, V., Domingues, M.R.M., Erny, G.L., Esteves, V.I., 2011b. Direct photodegradation of carbamazepine followed by micellar electrokinetic chromatography and mass spectrometry. Water Res. 45, 1095-1104. http://dx.doi.org/10.1016/j.watres.2010.10.037.

Canesi, L., Lorusso, L.C., Ciacci, C., Betti, M., Regoli, F., Poiana, G., Gallo, G., Marcomini, A., 2007. Effects of blood lipid lowering pharmaceuticals (bezafibrate and gemfibrozil) on immune and digestive gland functions of the bivalve mollusc, Mytilus galloprovincialis. Chemosphere 69, 994-1002. http://dx.doi.org/10.1016/j.chemosphere.2007.04.085.

Carregosa, V., Velez, C., Pires, A., Soares, A.M.V.M., Figueira, E., Freitas, R., 2014. Physiological and biochemical responses of the Polychaete Diopatra neapolitana to organic matter enrichment. Aquat. Toxicol. 155, 32-42. http://dx.doi.org/10.1016/j.aquatox.2014. 05.029.

Castro, H., Ramalheira, F., Quintino, V., Rodrigues, A.M., 2006. Amphipod acute and chronic sediment toxicity assessment in estuarine environmental monitoring: an example from Ria de Aveiro, NW Portugal. Mar. Pollut. Bull. 53, 91-99. http://dx.doi.org/10. 1016/j.marpolbul.2005.09.029.

Chen, H., Zha, J., Liang, X., Li, J., Wang, Z., 2014. Effects of the human antiepileptic drug carbamazepine on the behavior, biomarkers, and heat shock proteins in the Asian clam Corbicula fluminea. Aquat. Toxicol. 155, 1-8. http://dx.doi.org/10.1016/j.aquatox. 2011.07.017.

Contardo-Jara, V., Pflugmacher, S., Nützmann, G., Kloas, W., Wiegand, C., 2010. The $\beta-$ receptor blocker metoprolol alters detoxification processes in the non-target organism Dreissena polymorpha. Environ. Pollut. 158, 2059-2066. http://dx.doi.org/10. 1016/j.envpol.2010.03.012.

Contardo-Jara, V., Lorenz, C., Pflugmacher, S., Nutzmann, G., Kloas, W., Wiegand, C., 2011. Exposure to human pharmaceuticals carbamazepine, ibuprofen and bezafibrate causes molecular effects in Dreissena Polymorpha. Aquat. Toxicol. 105, 428-437. http://dx.doi.org/10.1016/j.aquatox.2011.07.017.

Coughlan, J., 1969. The estimation of filtering rate from the clearance of suspensions. Mar. Biol. 2, 356-358. http://dx.doi.org/10.1007/BF00355716.

Daughton, C.G., Ternes, T.A., 1999. Pharmaceuticals and personal care products in the environment: agents of subtle change? Environ. Health Perspect. 107, 907-938.

De Coen, W.M., Janssen, C.R., 1997. The use of biomarkers in Daphnia magna toxicity testing. IV. Cellular energy allocation: a new methodology to assess the energy budget of toxicant-stressed Daphnia populations. J. Aquat. Ecosyst. Stress. Recover. 6, 43-55. http://dx.doi.org/10.1023/A:1008228517955.

Dubois, M., Gilles, K.A., Hamilton, J.K., Rebers, P.A., Smith, F., 1956. Colorimetric method for determination of sugars and related substances. Anal. Chem. 28, 350-356. http://dx.doi.org/10.1021/ac60111a017.

Duquesne, S., Liess, M., Bird, D.J., 2004. Sub-lethal effects of metal exposure: physiological and behavioural responses of the estuarine bivalve Macoma balthica. Mar. Environ. Res. 58, 245-250. http://dx.doi.org/10.1016/j.marenvres.2004.03.066.

Fent, K., Weston, A., Caminada, D., 2006. Ecotoxicology of human pharmaceuticals. Aquat Toxicol. 76, 122-159. http://dx.doi.org/10.1016/j.aquatox.2005.09.009.

Ferrari, B., Paxéus, N., Giudice, R.L., Pollio, A., Garric, J., 2003. Ecotoxicological impact of pharmaceuticals found in treated wastewaters: study of carbamazepine, clofibric acid, and diclofenac. Ecotoxicol. Environ. Saf. 55, 359-370. http://dx.doi.org/10 1016/S0147-6513(02)00082-9.

Figueira, E., Cardoso, P., Freitas, R., 2012. Ruditapes decussatus and Ruditapes philippinarum exposed to cadmium: toxicological effects and bioaccumulation patterns. Comp. Biochem. Physiol. C 156, 80-86. http://dx.doi.org/10.1016/j.cbpc.2012.04.004.

Findlay, J.W., Dillard, R.F., 2007. Appropriate calibration curve fitting in ligand binding assays. Am. Assoc. Pharm. Sci. J. 9, E260-E267. http://dx.doi.org/10.1208/ aapsj0902029.

Freitas, R., Martins, R., Campino, B., Figueira, E., Soares, A.M.V.M., Montaudouin, X., 2014. Trematodes communities in cockles (Cerastoderma edule) of Ria de Aveiro (Portugal): influence of a contamination gradient. Mar. Pollut. Bull. 82, 117-126. http://dx.doi. org/10.1016/j.marpolbul.2014.03.012.

Gagné, F., Blaise, C., André, C., Salazar, M., 2006a. Effects of pharmaceutical products and municipal wastewaters on temperature-dependent mitochondrial electron transport activity in Elliptio complanata mussels. Comp. Biochem. Physiol. C 143, 388-393. http://dx.doi.org/10.1016/j.cbpc.2006.04.013.

Gagné, F., Blaise, C., Fournier, M., Hansen, P.D., 2006b. Effects of selected pharmaceutical products on phagocytic activity in Elliptio complanata mussels. Comp. Biochem. Physiol. C 143, 179-186. http://dx.doi.org/10.1016/j.cbpc.2006.01.008.

Gagné, F., Eullafroy, P., Blaise, C., 2006c. Development of a competitive enzymatic immuno-assay for carbamazepine in biological tissues. Fresenius Environ. Bull. 15, 1512-1516.
Garcia, S.N., Foster, M., Constantine, L.A., Huggett, D.B., 2012. Field and laboratory fish tissue accumulation of the anti-convulsant drug carbamazepine. Ecotoxicol. Environ. Saf. 84, 207-211. http://dx.doi.org/10.1016/j.ecoenv. 2012.07.013

Gobas, F.A.P.C., Morrison, H.A., 2000. Bioconcentration and biomagnification in the aquatic environment. In: Boethling, R.S., Mackay, D. (Eds.), Handbook of Property Estimation Methods for Chemicals. Lewis Publishers, Boca Raton, pp. 189-231 http://dx. doi.org/10.1201/9781420026283.ch9.

Gosling, E., 2003. Circulation, respiration, excretion and osmoregulation. In: Gosling, E. (Ed.), Bivalve Molluscs, Biology, Ecology and Culture. Blackwell Publishing, pp. 201-225 http://dx.doi.org/10.1002/9780470995532.ch7.

Gunnarsson, L., Jauhiainen, A., Kristiansson, E., Nerman, O., Larsson, D.G.J., 2008. Evolutionary conservation of human drug targets in organisms used for environmental risk assessments. Environ. Sci. Technol. 42, 5807-5813. http://dx.doi.org/10.1021/ es8005173.

Habig, W.H., Pabst, M.J., Jakoby, W.B., 1974. Glutathione S-transferases the first enzymatic step in mercapturic acid formation. J. Biol. Chem. 249, 7130-7139.

Heberer, Th., Reddersen, K., Mechlinski, A., 2002. From municipal sewage to drinking water: fate and removal of pharmaceutical residues in the aquatic environment in urban areas. Water Sci. Technol. 46, 81-88.

Johansson, L.H., Borg, L.A.H., 1988. A spectrophotometric method for determination of catalase activity in small tissue samples. Anal. Biochem. 174, 331-336. http://dx.doi.org/ 10.1016/0003-2697(88)90554-4.

Jonkers, N., Sousa, A., Galante-Oliveira, S., Barroso, C.M., Kohler, H.E., Giger, W., 2010. Occurrence and sources of selected phenolic endocrine disruptors in Ria de Aveiro, Portugal. Environ. Sci. Pollut. Res. 17, 834-843. http://dx.doi.org/10.1007/s11356009-0275-5.

King, F.D., Packard, T.T., 1975. Respiration and the activity of the respiratory electron transport system in marine zooplankton. Limnol. Oceanogr. 20, 849-854. http://dx. doi.org/10.4319/10.1975.20.5.0849.

Klosterhaus, S.L., Grace, R., Hamilton, M.C., Yee, D., 2013. Method validation and reconnaissance of pharmaceuticals, personal care products, and alkylphenols in surface waters, sediments, and mussels in an urban estuary. Environ. Int. 54, 92-99. http:// dx.doi.org/10.1016/j.envint.2013.01.009.

Li, Z.H., Zlabek, V., Velisek, J., Grabic, R., Machova, J., Randak, T., 2009. Responses of antioxidant status and $\mathrm{Na}+/ \mathrm{K}+$-ATPase activity in gill of rainbow trout, Oncorhynchus mykiss, chronically treated with carbamazepine. Chemosphere 77, 1476-1481. http://dx.doi.org/10.1016/j.chemosphere.2009.10.031.

Li, Z.H., Velisek, J., Zlabek, V., Grabic, R., Machova, J., Kolarova, J., Randak, T., 2010. Hepatic antioxidant status and hematological parameters in rainbow trout, Oncorhynchus mykiss, after chronic exposure to carbamazepine. Chem. Biol. Interact. 183, 98-104. http://dx.doi.org/10.1016/j.cbi.2009.09.009.

Liu, J., Lu, G., Xie, Z., Zhang, Z., Li, S., Yan, Z., 2015. Occurrence, bioaccumulation and risk assessment of lipophilic pharmaceutically active compounds in the downstream rivers of sewage treatment plants. Sci. Total Environ. 511, 54-62. http://dx.doi.org/10 1016/j.scitotenv.2014.12.033.

Malarvizhi, A., Kavitha, C., Saravanan, M., Ramesh, M., 2012. Carbamazepine (CBZ) induced enzymatic stress in gill, liver and muscle of a common carp, Cyprinus carpio J. King Saud Univ. Sci. 24, 179-186. http://dx.doi.org/10.1016/j.jksus.2011.01.001.

Martín-Díaz, M.L., Blasco, J., Sales, D., DelValls, T.A., 2007. Biomarkers study for sediment quality assessment in Spanish Ports using the crab Carcinus maenas and the clam Ruditapes philippinarum. Arch. Environ. Contam. Toxicol. 53, 66-76. http://dx.doi. org/10.1007/s00244-006-0121-4.

Martin-Diaz, L., Franzellitti, S., Buratti, S., Valbonesi, P.., Capuzzo, A., Fabbri, E., 2009. Effects of environmental concentrations of the antiepileptic drug carbamazepine on biomarkers and cAMP-mediated cell signaling in the mussel Mytilus Galloprovincialis. Aquat. Toxicol. 94, 177-185. http://dx.doi.org/10.1016/j.aquatox.2009.06.015.

Martínez-Bueno, M.J., Boillot, C., Fenet, H., Chiron, S., Casellas, C., Gómez, E., 2013. Fast and easy extraction combined with high resolution-mass spectrometry for residue analysis of two anticonvulsants and their transformation products in marine mussels. J. Chromatogr. A 1305, 27-34. http://dx.doi.org/10.1016/j.chroma. 2013.06.071.

Masilamoni, J.G., Nandakumar, K., Jesudoss, K.S., Azariah, J., Satapathy, K.K., Nair, K.V.K., 2002. Influence of temperature on the physiological responses of the bivalve Brachidontes Striatulus and its significance in fouling control. Mar. Environ. Res. 53, 51-63. http://dx.doi.org/10.1016/S0141-1136(01)00109-X.

Matozzo, V., Formenti, A., Donadello, G., Marin, M.G., 2012a. A multi-biomarker approach to assess effects of Triclosan in the clam Ruditapes philippinarum. Mar. Environ. Res. 74, 40-46. http://dx.doi.org/10.1016/j.marenvres.2011.12.002.

Matozzo, V., Binelli, A., Parolini, M., Previato, M., Masiero, L., Finos, L., Bressan, M., Marin, M.B., 2012b. Biomarker responses in the clam Ruditapes philippinarum and contamination levels in sediments from seaward and landward sites in the lagoon of Venice. Ecol. Indic. 19, 191-205. http://dx.doi.org/10.1016/j.ecolind.2011.06.020.

McEneff, G., Barron, L., Kelleher, B., Paull, B., Quinn, B., 2013. The determination of pharmaceutical residues in cooked and uncooked marine bivalves using pressurised liquid extraction, solid-phase extraction and liquid chromatography-tandem mass spectrometry. Anal. Bioanal. Chem. 405, 9509-9521. http://dx.doi.org/10.1007/ s00216-013-7371-6.

McEneff, G., Barron, L., Kelleher, B., Paull, B., Quinn, B., 2014. A year-long study of the spatial occurrence and relative distribution of pharmaceutical residues in sewage effluent, receiving marine waters and marine bivalves. Sci. Total Environ. 476, 317-326. http://dx.doi.org/10.1016/j.scitotenv.2013.12.123.

Metcalfe, C.D., Koenig, B.G., Bennie, D.T., Servos, M., Ternes, T.A., Hirsch, R., 2003. Occurrence of neutral and acidic drugs in the effluents of Canadian sewage treatment plants. Environ. Toxicol. Chem. 22, 2872-2880. http://dx.doi.org/10.1897/ $02-469$. 
Milan, M., Pauletto, M., Patarnello, T., Bargelloni, L., Marin, M.G., Matozzo, V., 2013. Gene transcription and biomarker responses in the clam Ruditapes philippinarum after exposure to ibuprofen. Aquat. Toxicol. 126, 17-29. http://dx.doi.org/10.1016/j.aquatox. 2012.10.007.

Mohapatra, D.P., Brar, S.K., Tyagi, R.D., Picard, P., Surampalli, R.Y., 2014. Analysis and advanced oxidation treatment of a persistent pharmaceutical compound in wastewater and wastewater sludge-carbamazepine. Sci. Total Environ. 470-471, 58-75. http:// dx.doi.org/10.1016/j.scitotenv.2013.09.034.

Monteiro, S.C., Boxall, A.B.A., 2010. Occurrence and fate of human pharmaceuticals in the environment. Rev. Environ. Contam. Toxicol. 202, 53-143. http://dx.doi.org/10.1007/ 978-1-4419-1157-5_2.

Oetken, M., Nentwig, G., Löffler, D., Ternes, T., Oehlmann, J., 2005. Effects of pharmaceuticals on aquatic invertebrates. Part I. The antiepileptic drug Carbamazepine. Arch. Environ. Contam. Toxicol. 49, 353-361. http://dx.doi.org/10.1007/s00244-004-0211-0.

Ohkawa, H., Ohishi, N., Yagi, K., 1979. Assay for lipid peroxides in animal tissues by thiobarbituric acid reaction. Anal. Biochem. 95, 351-358. http://dx.doi.org/10.1016/00032697(79)90738-3.

Parolini, M., Binelli, A., 2012. Sub-lethal effects induced by a mixture of three nonsteroidal anti-inflammatory drugs (NSAIDs) on the freshwater bivalve Dreissen polymorpha. Ecotoxicology 21, 379-392. http://dx.doi.org/10.1007/s10646-0110799-6.

Quinn, B., Gagné, F., Blaise, C., 2004. Oxidative metabolism activity in Hydra attenuata exposed to carbamazepine. Fresenius Environ. Bull. 13, 783-788.

Quinn, B., Gagné, F., Blaise, C., 2008. An investigation into the acute and chronic toxicity of eleven pharmaceuticals (and their solvents) found in wastewater effluent on the cnidarian, Hydra attenuata. Sci. Total Environ. 389, 306-314. http://dx.doi.org/10.1016/j. scitotenv.2007.08.038

Rahman, I., Kodel, A., Biswas, S.K., 2007. Assay for quantitative determination of glutathione and glutathione disulfide levels using enzymatic recycling method. Nat. Protoc. 1 3159-3165. http://dx.doi.org/10.1038/nprot.2006.378.

Ramirez, A.J., Mottaleb, M.A., Brooks, B.W., Chambliss, C.K., 2007. Analysis of pharmaceuticals in fish using liquid chromatography-tandem mass spectrometry. Anal. Chem. 79, 3155-3163. http://dx.doi.org/10.1021/ac062215i.

Riba, I., DelValls, T.A., Forja, J.M., Gómez-Parra, A., 2004. The influence of pH and salinity on the toxicity of heavy metals in sediment to the estuarine clam Ruditapes philippinarum. Environ. Toxicol. Chem. 23, 1100-1107. http://dx.doi.org/10.1897/ 023-601.
Robinson, H.W., Hogden, C.G., 1940. The biuret reaction in the determination of serum proteins. 1. A study of the conditions necessary for the production of a stable color which bears a quantitative relationship to the protein concentration. J. Biol. Chem. 135, 707-725.

Sacher, F., Lange, F.T., Brauch, H., Blankenhorn, I., 2001. Pharmaceuticals in groundwaters: analytical methods and results of a monitoring program in Baden-Württemberg, Germany. J. Chromatogr. A 938, 199-210. http://dx.doi.org/10.1016/S00219673(01)01266-3.

Smolders, R., De Boeck, G., Blust, R., 2003. Changes in cellular energy budget as a measure of whole effluent toxicity in zebrafish (Danio rerio). Environ. Toxicol. Chem. 22, 890-899. http://dx.doi.org/10.1002/etc.5620220429.

Smolders, R., Bervoets, L., De Coen, W., Blust, R., 2004. Cellular energy allocation in zebra mussels exposed along a pollution gradient: linking cellular effects to higher levels of biological organization. Environ. Pollut. 129, 99-112. http://dx.doi.org/10.1016/j. envpol.2003.09.027.

Sturve, J., Almroth, B.C., Förlin, L., 2008. Oxidative stress in rainbow trout (Oncorhynchus mykiss) exposed to sewage treatment plant effluent. Ecotoxicol. Environ. Saf. 70, 446-452. http://dx.doi.org/10.1016/j.ecoenv.2007.12.004.

Ternes, T.A., 1998. Occurrence of drugs in German sewage treatment plants and rivers. Water Res. 32, 3245-3260. http://dx.doi.org/10.1016/S0043-1354(98)00099-2.

Tsiaka, P., Tsarpali, V., Ntaikou, I., Kostopoulou, M.N., Lyberatos, G., Dailianis, S., 2013. Carbamazepine-mediated pro-oxidant effects on the unicellular marine algal species Dunaliella tertiolecta and the hemocytes of mussel Mytilus galloprovincialis. Ecotoxicology 22, 1208-1220. http://dx.doi.org/10.1007/s10646-013-1108-3.

Vernouillet, G., Eullaffroy, P., Lajeunesse, A., Blaise, C., Gagné, F., Juneau, P., 2010. Toxic effects and bioaccumulation of carbamazepine evaluated by biomarkers measured in organisms of different trophic levels. Chemosphere 80, 1062-1068. http://dx.doi. org/10.1016/j.chemosphere.2010.05.010.

Zhang, Y., Geißen, S, Gal, C. 2008. Carbamazepine and diclofenac: removal in wastewater treatment plants and occurrence in water bodies. Chemosphere 73, 1151-1161. http://dx.doi.org/10.1016/j.chemosphere.2008.07.086.

Zhang, W., Zhang, M., Lin, K., Sun, W., Xiong, B., Guo, M., Cui, X., Fu, R., 2012. Ecotoxicological effect of carbamazepine on Scenedesmus obliquus and Chlorella pyrenoidosa. Environ. Toxicol. Pharmacol. 33, 344-352. http://dx.doi.org/10.1016/j. etap.2011.12.024 